\title{
Reading Comprehension Skills in Terms of the Sentiments Given in Reading Texts
}

\author{
Esra Çetin', Sabri Sidekli \\ ${ }^{1}$ Institute of Educational Sciences, Uludağ University, Turkey \\ ${ }^{2}$ Department of Elementary Education, Faculty of Education, Mugla Sitk1 Kocman University, Turkey
}

\begin{tabular}{l}
\hline Article Info \\
\hline Article history: \\
Received Jun 23, 2018 \\
Revised Jul 26, 2018 \\
Accepted Sep 27, 2018 \\
\hline
\end{tabular}

\section{Keyword:}

Reading

Reading comprehension

Sentiment

Sentiments in reading texts

Understanding

\begin{abstract}
This study aimed to investigate reading comprehension skills of the 4th graders in terms of the sentiments given in the reading text and to reveal that whether there is a meaningful difference for reading comprehension skills of different student groups or not. The sampling of the study has been selected randomly and it has been limited in primary schools in Muğla, Turkey. The sampling has been covered totally 3874 th graders, 209 of them have been female and 178 of them have been male students. The data collection instruments in the study have been determined as a personal information form and an achievement test on reading comprehension skills in terms of sentiments given in the reading texts. The answers of the students for the achievement test have been analyzed via percentage, frequency and arithmetic mean. According to the findings of the study; For the sentiments given in the reading texts, in line, the mostly understandable sentiments are happiness, fear and sadness. Additionally, there was a mean difference in terms of the level of reading comprehension skills. The students were mostly aware of texts containing happiness, and they understood sorrow in texts at least.
\end{abstract}

Copyright (C) 2018 Institute of Advanced Engineering and Science. All rights reserved.

\section{Corresponding Author:}

Esra Çetin,

Institute of Educational Sciences

Uludağ University, Turkey

Email: esractn_48@windowslive.com

\section{INTRODUCTION}

The reading is a process in which seeing, understanding and comprehending the words, sentences, punctuation and other elements in a written text are needed. Reading is also a comprehension activity which is a combination of cognitive skills and psychomotor skills [1,2]. According to Güneş [3] who defines reading as referring constructivism, reading is a complex process that consists of different operations in brain such as seeing, understanding, vocalization, comprehension and constructing. This process starts with comprehending signs, letters and symbols. At the end of the comprehension process, words are recognized and sentences can be understood via concentration. The important points of paragraphs are selected by readers and the selected points are operated via ordering, classification, coherence, investigation, analysis, synthesis and evaluation. At the end of the reading process, readers re-comprehend the meaning as their previous knowledge.

The main aim of reading presents the some basic strategies and techniques to students for understanding both the world and themselves, improving expectations and interests, being independent conceptual people. Comprehension can be thought as the most important element for reading and the main aim of teaching comprehension is providing students to think and react on reading texts and preparing them to understand a reading text [4]. Pardo defines comprehension as a constructivist process in which readers combine their previous knowledge and context of the reading text $[5,6,7]$. 
The basic part of the reading process is the understanding of the main idea in a text and using this knowledge. In order to accomplish this aim, readers use some reading texts that can be reached in their environment. Thanks to these texts, there is an interaction between reader and writer; readers can reach the meaning pointed by writer. Therefore, readers begin to improve reading and comprehension skills [8]. The reading texts are the most basic instrument for readers on reaching the aims. The learner motivation can be improved via attention-paying reading texts [9]. The learner motivation can change with regard to the level of reading text. Yet, if learners believe that they are effective and talented in an activity, their self-efficacy and aptitude can improve easily. For this reason, learners should be interested in reading texts that can be suitable for them $[10,11,12]$. This kind of reading text may be effective for reading aptitude, motivation and reading routines. It is seen in some studies that learners who have higher reading motivation, self-efficacy and reading habits can have more reading comprehension abilities than the others [13, 14]. Therefore, it is important that learners should come across reading texts that are effective and suitable for them. Teachers should also know the characteristics of a reading text while teaching language skills, because reading texts can combine people with their environment and social life as regarding their inner world.

In Turkish language course books, there have been lots of reading texts which are different genres and written by different authors. These texts should be selected as considering the themes, but selecting a text just referring themes is not enough to determine a reading text. At the same time, the sentiment given in a text should be appropriate for the psychology of learners and it helps improving a positive personality. "Selecting some reading texts that consist of fantastic, magical, unreal and attracting elements prevents to improve thinking, comprehending, analyzing, searching, investigating, discovering, cooperating, problemsolving, and deciding abilities for learners" [15].

The psychology has also a significant role on improving reading habits. Learners who have emotional problems cannot be motivated while reading a text and they cannot reach the desirable level for reading activities. In the studies on the relationship between reading habits and learners' psychology, it is stated that there is a relation between these two concepts $[16,17]$. However, it is not known that whether there is a relationship between reading texts consisting of different sentiments and reading comprehension or not. In order to answer this question, it is thought that a study may be conducted on searching the relationship between sentiments given in a reading text and reading comprehension level of learners.

People do not have the same desire for reading and they cannot improve their reading skills in the same level, because there are individual and environmental differences [22]. Having different previous knowledge, individual differences, interests and sentiments can be effective while comprehending a reading text. It is a necessity that the factors affecting reading comprehension skills should be determined. It is especially known that how learners comprehend a text via sentiments easily. However, there is gap on the relationship between different sentiments and reading comprehension skills of learners; if there is a relationship between them, which sentiments are more effective while reading and also it is not known that which kind of factors can affect this relationship. For this reason, the examination on the effects of different sentiments for reading comprehension should be studied in a research. In this study, accordingly, the effects of some sentiments known as sorrow, fear and happiness are aimed to be determined during the reading activities for the $4^{\text {th }}$ graders in primary schools.

\section{RESEARCH METHOD}

In this study, descriptive research method was used. If the main aim of a study is stating the description for a problem and defining the study in the current position of it, descriptive research model is seen as a suitable model for the research. According to Karasar [18], general descriptive model is a research method in which there is a universe consisting of many different elements and in order to generalize the results, a small group of this universe is examined deeply to get information about the whole universe.

\subsection{Universe and Sampling of the Study}

The universe of the study is limited to $4^{\text {th }}$ grade students in primary state schools that were randomly selected from Muğla. The sample of the study consisted of randomly selected 387 students in the $4^{\text {th }}$ grade in 2016-2017 autumn semester. The sample was 54\% $(n=209)$ female and $46 \%(n=178)$ was male.

\subsection{Data Collection Instruments}

As for data collection instruments, 6 assessment instruments conducted as achievement test were used for the aim of determining the effects of sentiments, sorrow, fear and happiness, given in the reading texts on the $4^{\text {th }}$ graders' reading comprehension skills. All of the reading texts that were used in the study had 285 words. There were two different reading texts for each one of the sentiments. For the items prepared for the assessment instruments, 3 experts in this field were consulted.

IJERE Vol. 7, No. 4, December 2018: $317-330$ 
In order to supply reliability for the instruments, there was a pilot study conducted with 70 students. After the pilot study, item analysis was completed via ITEMAN program. At the end of the analysis, the items that were lower level for item options were reviewed and they were rewritten after expert consultation. Finally, reading comprehension test which had 13 items was completed. As a result of the pilot study, the reliability coefficient of the test was found as .84; difficulty index was found as .76 and the value of distinctiveness was found as .88 for the sentiment of happiness category. As referring this result, it was seen that the reliability, difficulty index and the value of distinctiveness of the test was in high level. As for the sentiment of fear, it was found that the reliability coefficient was .70; difficulty index was .53 and the value of distinctiveness was .72. According to this result, the reliability and difficulty index was in medium level and the value of distinctiveness of the test was in high level for fear category. As for the reading texts consisting of sorrow, the reliability coefficient was found as .77; difficulty index was found as .63 and the value of distinctiveness was found as .80 . For this result, it was seen that the reliability, difficulty index and the value of distinctiveness of test was in high level for the sentiment of sorrow. At the end of the item analysis, it was seen that each one of the items had different strengths; therefore, $\mathrm{Kr}$-20 value was used to calculate the reliability of the test.

In the pilot study, it was observed that all of the students could complete the test in 40 minutes. For this reason, in the main study, the duration for the test was accepted as 40 minutes. The main study was completed in 108 sessions.

In the reading comprehension test, 8 items were used for superficial comprehension and 5 of them were used for the in-depth comprehension. As for a sample for superficial comprehension, the question "Who is the protagonist of the reading text?" was used for superficial comprehension. On the other hand, for the indepth comprehension, the question "Explain an event or experience that is similar to the event in the reading text." was used for the test.

\subsection{Data Analysis}

The data collected via achievement tests and data collection instruments was analyzed in terms of the aim of the study. The data analysis was completed via ITEMAN and SPSS 20 programs.

At the beginning of the analysis, in order to determine the statistical tests, firstly, normal distribution value of the data was calculated. For this aim, Kolmogorov-Smirnov test was used. Büyüköztürk [60] stated that if the number of participants was higher than 50, Kolmogorov-Smirnov test (K-S) was used to calculate the normal distribution value of the test. In this study, since the number of participants was higher than 50 $(\mathrm{N}=387)$, this test was used for normal distribution value. As for the normality distribution, $p>.05$ value was taken into consideration. The analysis of the test is described in Table1.

Table 1. The Results of Kolmogorov-Smirnov Test

\begin{tabular}{cccc}
\hline Achievement Tests & Statistics & Df & P \\
\hline Sentiment of Fear 1 & .061 & 387 & .001 \\
Sentiment of Sorrow 1 & .097 & 387 & .000 \\
Sentiment of Happiness 1 & .141 & 387 & .000 \\
Sentiment of Fear 2 & .074 & 387 & .000 \\
Sentiment of Sorrow 2 & .062 & 387 & .000 \\
Sentiment of Happiness 2 & .097 & 387 & .000 \\
\hline
\end{tabular}

As a result of the analysis, it was found that the test did not have normal distribution $(p \leq .00)$. For this reason, arithmetic mean, standard deviation and percentage values were used for the analysis. For the comparison of two variables, Mann Whitney U test was used since there was not normal distribution. As for the comparison of more variables, Kruskall Wallis test was used. In order to determine the sides of the comparisons, Mann Whitney-U test was used. For the aim of analyzing whether there was a meaningful difference between two scores which were got from the similar data, Wilcoxon Signed Ranks Test was used.

Each one of the items in the achievement test was valued at " 10 " points. The highest score of the test could be " 130 " points and the lowest one could be " 0 " point.

The scores of the achievement test were ranked as: 1) Independent Reader level: $90-100 \% ; 117-130$ points; 2) Instructional Reader Level: 70-89 \%; 91-116 points; 3) Frustrational Reader Level: 0-69 \%; 0-90 points [61]. 


\section{RESULTS AND DISCUSSION}

\subsection{Findings for the First Sub-Problem}

As for the first research question "What is the general position for reading comprehension skills of the $4^{\text {th }}$ graders in primary schools?" the reading comprehension test was used for the $4^{\text {th }}$ graders and the current position of them was determined via this test. In Table 2, the reading comprehension skills of the students were analyzed in terms of independent, instructional and frustrational level.

Table 2. Descriptive Analysis of Reading Comprehension Skills for the Students

\begin{tabular}{crrrr}
\hline Reading Comprehension & \multicolumn{1}{c}{$\mathrm{N}$} & $\%$ & $\overline{\mathbf{X}}$ & Ss \\
\hline Frustrational Level & 301 & 77.8 & & \\
Instructional Level & 86 & 22.2 & 80.83 & 13 \\
Independent Level & 0 & 0 & & \\
\hline
\end{tabular}

In Table 2, it was seen that the general score of the participants was 80.83 . in this sense, it was found that students could comprehend a reading text in $62 \%$. According to the data, since the percentage of the reading comprehension level was lower than $70 \%$, it was seen as frustrational level.

When the results were analyzed for six different reading texts, it was seen that their reading comprehension level was in frustrational level. $86(22.2 \%)$ of the participants' $(\mathrm{N}=387)$ reading comprehension skills were found as instructional level and $301(77.8 \%)$ of them were found as in frustrational level. It was stated that students could not comprehend a reading text independently. This result showed that students had problem on reading comprehension.

This result suggests that the students have some problems on reading comprehension. The reason of this result could be about the problems of students on reading fluently and basic reading skills. It is not expected that if a student cannot read correctly, s/he can be successful in reading comprehension. In the previous studies, it was stated that the students who have been in frustrational level during reading process have also been in frustrational level in reading comprehension skills [19, 20, 21, 22]. For this reason, in order to in independent level during reading comprehension process, the students should be in independent level while reading activities. Thanks to independent reading comprehension skills, the academic achievement of the students can develop easily.

Reading Comprehension Level of the Students in terms of Gender

The frequency and percentage scores that were related to reading comprehension level of the students are explained in Table 3 in terms of gender differences.

Tablo 3. Reading Comprehension Levels and Descriptive Analysis of the Students for Gender Differences

\begin{tabular}{|c|c|c|c|c|c|}
\hline Gender & Reading Level & $\mathrm{N}$ & $\%$ & $\overline{\mathbf{X}}$ & Ss \\
\hline \multirow{4}{*}{ Female } & Frustrational L. & 149 & 71.3 & \multirow{3}{*}{83.6} & \multirow{4}{*}{13.3} \\
\hline & Instructional L. & 60 & 28.7 & & \\
\hline & Independent L. & 0 & & & \\
\hline & Frustrational L. & 152 & 85.4 & \multirow{3}{*}{77.5} & \\
\hline \multirow{2}{*}{ Male } & Instructional L. & 26 & 14.6 & & \multirow{2}{*}{12.2} \\
\hline & Independent L. & 0 & & & \\
\hline
\end{tabular}

When Table 3 was analyzed, it was observed that female participants had higher reading comprehension skills $(\overline{\mathrm{X}}=83.6)$ than male participants $(\overline{\mathrm{X}}=77.5)$. When the reading comprehension skills were analyzed, it was seen that 60 of 209 female participants $(28.7 \%)$ were in instructional level and 149 of them $(71.3 \%)$ were in frustrational level. As for male participants, 152 of them $(85.4 \%)$ were in frustrational level and 26 of them (14.6) were in instructional level.

In the international exams for reading comprehension, it was stated that the female students have had higher scores than the male students in reading comprehension skills [23, 24]. In the previous studies, it was seen that the female students could use both of the brain hemispheres during a reading activity and they could heavily use their right hemisphere; however the male students could activate their left hemisphere during a reading activity $[25,26,27]$. While left hemisphere uses the numerical codes in a reading process, right hemisphere uses some visual codes $[28,29]$. For this reason, if both of the hemispheres are used during a reading activity, the reading comprehension can be supported.

IJERE Vol. 7, No. 4, December 2018: $317-330$ 
In literature, accordingly, there have been a number of studies on indicating that female students have been more successful than male students in terms of reading comprehension skills [13][30-34]. Sidekli [21] suggested that the reason of it could about female students' responsibilities; male students' much more outdoor activities; having much more indoor activities by female students, having responsibilities for studying lessons and much more reading by female students.

The Reading Comprehension Level of the Students in terms of Superficial and In-depth Comprehension Skills Superficial comprehension items were generally based on the easily-answered questions and actions or information stated directly in the text. In-depth comprehension items were based on the questions that were not easily answered and needed to get a logical understanding for the text. The level of students for the superficial and in-depth comprehension skills is written in Table 4.

Table 4. The Reading Comprehension Level of the Students in terms of Superficial and In-depth

\begin{tabular}{|c|c|c|c|c|c|}
\hline Items level & Comprehension level & $\mathrm{N}$ & $\%$ & $\overline{\mathbf{X}}$ & Ss \\
\hline & Frustrational L. & 92 & 23.8 & & \\
\hline \multirow[t]{2}{*}{ comprehension } & Instructional L. & 259 & 66.9 & 7.58 & 1.10 \\
\hline & Independent $\mathrm{L}$. & 36 & 9.3 & & \\
\hline \multirow{3}{*}{$\begin{array}{c}\text { In-depth } \\
\text { comprehension }\end{array}$} & Frustrational L. & 384 & 99.2 & & \\
\hline & Instructional L. & 3 & .8 & 4.03 & 1.16 \\
\hline & Independent L. & 0 & & & \\
\hline
\end{tabular}

In table 4 , it was found that the score of superficial comprehension $(\bar{X}=7.58)$ was higher than the score of in-depth comprehension skills $(\overline{\mathrm{X}}=4.03)$. as for in-depth comprehension, it was observed that students were generally in frustrational level. In superficial comprehension skills, 36 of 387 students $(9.3 \%)$ were in independent level; 259 of them $(66.9 \%)$ were in instructional level and 92 of them $(23.8 \%)$ were in frustrational level. According to this result, it was stated that students had problems on answering the questions based on the superficial comprehension skill. Even if the items in this category were based the actions directly given in the text, the students had problems on answering them. For the in-depth comprehension skills, 384 of the students $(99.2 \%)$ were in frustrational level and 3 of them $(.8 \%)$ were in instructional level. This result indicated that students had problem on in-depth reading comprehension skills and they could not easily answer the question in this category.

In the study by Sidekli, it was seen that the students had problems on reading comprehension deeply and they could not connect the reading text and their experiences, so they could not comprehend a reading text easily; also they could not connect the previous reading during in-depth reading. It was also concluded that the students had problems while answering the questions about the in-depth reading comprehension and it was seen that either they could not answer a question correctly or they could answer it insufficiently [35]. It is thought that if the texts are read intertextually, it can be helpful for both reading comprehension and succeeding the steps of comprehension namely knowledge, comprehension, practice and evaluation [36, 37]. That is, it can be thought that intertextually reading can support in-depth reading comprehension skills.

\subsection{Findings for the Second Sub-Problem}

In order to answer the second research question "What is the general position for reading comprehension skills of the $4^{\text {th }}$ graders in primary schools in terms of the sentiments given in reading texts?" The reading comprehension skills of the students on the area of happiness, sorrow and fear was analyzed. The results of this analysis are presented in Table 5.

Table 5. The Descriptive Analysis of the Reading Comprehension Skills on Fear, Happiness and Sorrow

\begin{tabular}{ccrccc}
\hline Texts & Reading Comprehension Skills & \multicolumn{1}{c}{ N } & $\%$ & $\overline{\mathbf{X}}$ & Ss \\
\hline \multirow{2}{*}{ Texts consisting of } & Frustrational L. & 319 & 82.4 & & \\
Fear & Instructional L. & 68 & 17.6 & 76.46 & \multirow{2}{*}{15.53} \\
& Independent L. & 0 & & & \\
Texts consisting of & Frustrational L. & 332 & 85.8 & & \\
Sorrow & Instructional L. & 55 & 14.2 & 74.02 & \multirow{2}{*}{15.57} \\
& Independent L. & 0 & & & \\
Texts consisting of & Frustrational L. & 150 & 38.8 & & \\
Happiness & Instructional L. & 233 & 60.2 & \multirow{2}{*}{92.00} & \multirow{2}{*}{15.23} \\
\hline
\end{tabular}

The Examination of the 4th Graders' Reading Comprehension Skills in Terms of ... (Esra Çetin) 
In Table 5 , it is seen that the mean score of the $4^{\text {th }}$ graders on the texts consisting of fear was 76.46 , on the texts consisting of sorrow was 74.02 and on the texts consisting of happiness was 92.00 . The students were mostly successful while reading the texts consisting of happiness and they were unsuccessful for the texts on sorrow. When the texts were analyzed, it was stated that the students were in frustrational level for the texts consisting of sorrow and fear and they were in instructional level for the texts on happiness.

When the reading comprehension level of the $4^{\text {th }}$ graders was analyzed, it was concluded that 319 of 387 students $(82.4 \%)$ were in frustrational level for the texts consisting of fear and 68 of them $(17.6 \%)$ were in instructional level for the same texts. As for the texts consisting of sorrow, 332 of the students $(85.8 \%)$ were in frustrational level and 55 of them $(14.2 \%)$ were in instructional level. The most problematic sentiment for the students was determined as sorrow at the end of the analysis. For the texts consisting of happiness, it was found that 150 of the students $(38.8 \%)$ were in frustrational level and 233 of them $(60.2 \%)$ were in instructional level and 4 of them (1\%) were in independent level. At the end of the analysis, it was seen that the only group consisting of students in independent level was the texts on happiness.

In general, the success level of the students was stated in order as happiness, fear and sorrow for reading comprehension on sentiments given in reading texts. The reason of that result could be about the definition on reading comprehension. Reading comprehension directs the determination of techniques and strategies for reading comprehension as using of the previous knowledge. In this sense, there is a relationship between reading comprehension and the previous knowledge $[38,39]$. The sentiments in the previous knowledge of the students can also be effective for reading comprehension. For this reason, the sentiments mostly felt by readers can increase the previous knowledge for this sentiment. If a sentiment given in a reading text is mostly felt by reader in his/her previous life, it can develop reading comprehension.

Some of the commonly felt sentiments are envy, furiousness, happiness, fear, sorrow and pleasure. Happiness and fear have a major role for children and the mostly seen sentiment is happiness for children $[27,40]$. The success of the reading comprehension on the texts consisting of happiness can be arisen by the previous knowledge of the children on happiness.

Human-beings revise their physical and emotional experiences before each one of their actions. They also discuss the meaning of an action as referring their own experiences. Sentiments step in this position and they categorize the experiences. After that, the mental abilities step in for decision and it help the evaluation. In other words, the mental analysis of sentiments is completed via thinking. In this case, it can be said that sentiments create a "meaning pool" for readers on whether something is confident or not and intelligence puts the ideas on this field in a mental process. Accordingly, it can be thought that sentiments are input that are coming before analysis [41]. During reading, readers review their previous knowledge and they try to make a connection between the context of a reading text and their previous knowledge. At this point, sentiments organize experiences and it helps reading comprehension with the help of thinking abilities. If readers direct their emotions and ideas in a balance, they can succeed comprehension in an effective way. If one of them is stated more strong than the other, there can be a problem for reading comprehension process.

At the end of the studies in this field, Goleman states that humans have two brains, two intelligences and two minds as emotional and cognitive ones; and states that not only IQ but also emotional intelligence is significant. In general, emotional and cognitive intelligence are in a balance. But, nevertheless, emotional and cognitive intelligence are semi-independent abilities. Both of them reflect the functions of actions that are both different from each other and related to each other. Most of the time, two kinds of intelligence collaborate heavily; sentiments are indispensable part of ideas and ideas are also indispensable part of sentiments or emotions. For an emotional situation, emotions are activated faster than the ideas and they are used before thinking [42]. The reading texts consisting of sentiments can also activate the emotional intelligence since students can behave via their emotions before thinking correctly.

Emotions directly affect the functions in human brain. If the emotion is positive, brain uses a single communication method; if there is a negative emotion, brain uses different methods for different parts of the functions. That is, emotions can cause different actions in human brain [43]. If emotions cause different actions in human brain, they can affect reading comprehension skills of the students.

As for sorrow, brain begins making new plans and it suspends thinking process of a human [42]. If students feel the same sorrow in your own brain, it may prevent thinking and students can be unsuccessful for these kinds of reading texts.

For the sentiment of happiness, in human brain there is a new energy and it also prevents negative emotions. It helps being calm and it may relax the human body; and it may motivate people to do something [42]. If students feel the happiness stated in a reading texts, it may be helpful for focusing on the text and they can be more successful for the reading comprehension process. Accordingly, happiness is thought as a positive emotion by human brain and brain reflects positive reactions for this sentiment. Therefore, information given in this kind of reading text is stored as a positive knowledge. So, it can be easily remembered. Since it is easily stored, it can be easily remembered. In the study conducted by Gür [44] that is

IJERE Vol. 7, No. 4, December 2018: $317-330$ 
about the effect of learning via smiling on success, it was seen that the reading activities that were based on smiling could affect positively control group. Ashby, Isen \& Turken [45] declared that there was an increase in dopamine after a positive situation and it could affect cognitive intelligence positively. According to these results, learning and emotions are concentric.

During fear, human body is shocked for a while. The human brain, on the other hand, starts secreting hormone to alarm it. It concentrates on attention to evaluate something [42]. If students feel just the sentiment of fear in a reading text, they can focus only on fear and they can ignore other situations; for this reason, the students might be unsuccessful for the reading comprehension skill on the sentiment of fear.

The statement of the Reading Comprehension Skills on Sentiments in terms of Gender Differences

The frequency, percentage, arithmetic mean and standard deviation scores of the students on reading comprehension skills for sentiments was given in Table 6 in terms of gender differences.

Table 6. The Descriptive Analysis of the Reading Comprehension Skills on Sentiments in terms of Gender Differences

\begin{tabular}{|c|c|c|c|c|c|c|c|c|c|}
\hline \multirow[b]{2}{*}{ Texts } & \multirow[b]{2}{*}{$\begin{array}{c}\text { Reading } \\
\text { Comprehension Level }\end{array}$} & \multicolumn{4}{|c|}{ Female students } & \multicolumn{4}{|c|}{ Male Students } \\
\hline & & $\mathrm{N}$ & $\%$ & $\bar{X}$ & Ss & $\mathrm{N}$ & $\%$ & $\overline{\mathrm{X}}$ & Ss \\
\hline Texts & Frustrational & 160 & 76.6 & & & 159 & 89.3 & & \\
\hline Fear & Independent & 0 & & & & 0 & & & \\
\hline Texts & Frustrational & 176 & 84.2 & & & 156 & 87.6 & & \\
\hline consisting of & Instructional & 33 & 15.8 & 76.27 & 14.86 & 22 & 12.4 & 7127 & 1600 \\
\hline Texts & Frustrational & 63 & 30.1 & & & 87 & 48.9 & & \\
\hline consisting of & Instructional & 142 & 67.9 & 95.05 & 13.74 & 91 & 51.1 & 88.41 & 16.13 \\
\hline Happiness & Independent & 4 & 1.9 & & & 0 & & & \\
\hline
\end{tabular}

In Table 6, it is analyzed that the arithmetic mean of the female students on texts consisting of fear was $(\bar{X}=79.50)$, however the score of male students was $(\bar{X}=72.90)$. The arithmetic mean of the female students on texts consisting of sorrow was $(\overline{\mathrm{X}}=76.27)$, however the score of male students was $(\overline{\mathrm{X}}=71.37)$. The arithmetic mean of the female students on texts consisting of happiness was $(\bar{X}=95.05)$, however the score of male students was $(\overline{\mathrm{X}}=88.41)$. In general, it was stated the score of the female students was higher than the male students for all the sentiments. The most successful texts for two genders were on happiness and the least were on fear.

For the texts consisting of fear, it was seen that 160 of 209 female students $(76.6 \%)$ were in frustrational level and 49 of them $(23.4 \%)$ were in instructional level. For the male students, on the other hand, it was seen that 159 of 178 male students $(89.3 \%)$ were in frustrational level and 19 of them $(10.7 \%)$ were in instructional level. It was concluded that the male students were more in frustrational level than the female students and they were less in instructional level. For the texts consisting of sorrow, it was seen that 176 of 209 female students $(84.2 \%)$ were in frustrational level and 33 of them $(15.8 \%)$ were in instructional level. For the male students, on the other hand, it was seen that 156 of 178 male students $(87.6 \%)$ were in frustrational level and 22 of them (12.4\%) were in instructional level. For the texts consisting of happiness, it was seen that 63 of 209 female students $(30.1 \%)$ were in frustrational level; 142 of them $(67.9 \%)$ were in instructional level and 4 of them (1.9\%) were in independent level. For the male students, on the other hand, it was seen that 87 of 178 male students $(48.9 \%)$ were in frustrational level and 91 of them $(51.1 \%)$ were in instructional level. In the analysis, it was also stated that all of the students in independent level were female.

Additionally, it was seen that all of the student who were in independent level for reading comprehension were determined as female students. It was also stated that the female students were more successful than the male students in terms of the sentiment of happiness which the least score was pointed for frustrational level. It was determined that the most meaningful difference was seen in the texts consisting of happiness. Accordingly, the female students were more successful than the male students in terms of the sentiment of happiness. However, although the male students had the highest point in happiness level, there was a meaningful difference between the male and female students for that sentiment. Larsen and Diener [46] stated that females could reflect themselves easily in both positive and negative sentiment levels and there was a significant role of gender difference in terms of the density of sentiments, and they clarified that females had more emotional density than males in each one of the age categories. According to Duyan, Uçar and Kalafat [47], men could learn escaping from the sentiment if they began to feel frailty (for instance 
sorrow). On the contrary, women could come close to emotions, because feelings and emotions could help to have empathy.

Because of the reasons mentioned above female students could be more successful than male students while comprehending reading texts consisting sentiments. Accordingly, while female students could make connection between their previous knowledge and reading experiences, male students could have problems for reading comprehension since they have tried to escape from some sentiments.

\subsection{Findings for the Third Sub-Problem}

In order to answer the third research question "Is there any meaningful difference between the different sentiments and reading comprehension skills of the $4^{\text {th }}$ graders?" the reading comprehension skills of the students on the area of happiness, sorrow and fear was analyzed. The data collected in the study is described in Table 7.

Table 7. The Differences on the $4^{\text {th }}$ Graders' Reading Comprehension Level in terms of the Sentiments The Results of Wilcoxon Signed Rank Test

\begin{tabular}{ccccccc}
\hline Score & Ranks & $\mathrm{N}$ & Mean Rank & Total Rank & $\mathrm{z}$ & $\mathrm{p}$ \\
\hline \multirow{2}{*}{ Happiness- } & Negative Rank & 47 & 72.99 & 3430.50 & & \\
Fear & Positive Rank & 335 & 208.13 & 69722.50 & -15.349 & .000 \\
& Equal & 5 & & & & \\
Segative Rank & 222 & 200.95 & 44612.00 & 2.516 & .000 \\
& Positive Rank & 162 & 180.91 & 29308.00 & -3.516 & \\
Sorrow-Fear & Equal & 3 & & & & \\
& Negative Rank & 348 & 198.39 & 69039.50 & 3731.50 & -15.181 \\
Happiness & Positive Rank & 33 & 113.08 & & & \\
\hline
\end{tabular}

As a result of Wilcoxon Signed Rank Test, it was seen that the mean score of the texts consisting of happiness was $(\bar{X}=92.00)$ and the mean score of the texts consisting of fear was $(\bar{X}=76.46)$. When Table 7 was analyzed, it was seen that there was a statistically mean difference $(\mathrm{z}$ happiness-fear $=-15.349, \mathrm{p}<.05)$. In Table 7 , it was seen that the mean score of the texts consisting of fear was $(\bar{X}=76.46)$ and the mean score of the texts consisting of sorrow was $(\overline{\mathrm{X}}=74.02)$. When Table 7 was analyzed, it was seen that there was a statistically mean difference $(\mathrm{z}$ fear-sorrow $=-3.181, \mathrm{p}<.05)$. It was also seen that the mean score of the texts consisting of happiness was $(\overline{\mathrm{X}}=92.00)$ and the mean score of the texts consisting of sorrow was $(\overline{\mathrm{X}}=74.02)$. When Table 7 was analyzed, it was seen that there was a statistically mean difference $(\mathrm{z}$ sorrow-happiness $=-$ $15.181, \mathrm{p}<.05)$.

The students were successful in the sentiments as order of happiness, fear and sorrow. According to the study, reading correctly and fluently causes responding certain and fast as emotionally and behavioral answers. The lack of that ability can cause answering wrong or inadequately [48]. Students who can easily correctly understand the sentiments given in reading texts can reflect fast and correct. On the other hand, the students who have problems on understanding a sentiment given in a reading text may have problems on answering or they may answer wrongly. In this sense, it can be said that emotional intelligence effects reading comprehension.

The preference of students for reading texts consisting of amazing, imaginary and fantastic elements prevents some abilities such as thinking, comprehending, examining, searching, discovering, cooperating, problem-solving, deciding and entrepreneurship [15]. Because reading texts consisting of sorrow and fear may keep students away from the real world, their comprehension skills can be in a lower degree than the texts consisting of happiness.

The reading texts consisting of sorrow and fear may cause feeling sorrow and fear. According to Spitzer [49], in this situation, stress hormones are activated and it can have two results; whether stress hormones prevents item transitions in cells and it prevents learning; that is it blocks learning or learning is completed but it is done with feeling stress and fear. So, knowledge is stored with these negative emotions and whenever learners remember this knowledge, they feel uncomfortable. Remembering a painful event creates sorrow and irritation in human brain because of the same reason that was mentioned above.

One of those two results can be valid for the students who read the texts containing those two sentiments namely sorrow and fear. That is, stress hormones can prevent learning and thinking abilities can be blocked, or learning can be completed with the sentiments namely both sorrow and fear. Since students feel uncomfortable for these two sentiments, their reading comprehension level can be lower.

IJERE Vol. 7, No. 4, December 2018: $317-330$ 
In contrast to a stressful atmosphere, in a context in which students feel relaxed, confident, happy and enjoyed learners can comprehend a reading text with positive emotions; so both their reading comprehension skills and motivation can be improved.

Emotions carry a huge energy with them. If these emotions are accepted accordingly and expend enough time to understand emotions, all of emotions can be tools that are given for human-beings. People can go on their life as more positively, constructivist, productive and effective if they can direct their own emotions in correct times. Briefly, both negative and positive emotions are belonged to people and they should learn to live with them.

Children can direct their own emotion when they are about ten years. If the actions are under their own control, they use problem-solving strategies, but if the problem in not under the control, they try to find new ways to solve problem. The use of intrinsic strategies helps children to have a positive sense of self and a positive perspective for the problems [50]. It can be said that students are inadequate to control their own emotions because there is a difference between them in terms of reading comprehension skills on the texts consisting of sentiments. It can be also stated that since children cannot direct their own emotions, they have lower score on the texts consisting of negative sentiments.

\subsection{Findings for the Forth Sub-Problem}

In order to answer the forth research question "According to the sentiments given in reading texts, is there any meaningful difference between gender and reading comprehension skills of the $4^{\text {th }}$ graders?" the reading comprehension skills of the students were analyzed.

Mann Whitney - U test results that were collected in the study for the reading comprehension statements of the students in terms of gender differences are presented in Table 8.

Table 8. Mann Whitney - U Test Results for the Reading Comprehension Statements of the Students in Terms of Gender Differences

\begin{tabular}{cccccc}
\hline Gender & $\mathrm{N}$ & Mean Rank & Total Rank & $\mathrm{U}$ & $\mathrm{p}$ \\
\hline Male & 178 & 164.99 & 29368.00 & 13437.00 & .000 \\
Female & 209 & 218.71 & 45710.00 & & \\
\hline
\end{tabular}

In Table 8 , it is stated that there was a mean difference $(U=13437.00, p<.05)$ between the reading comprehension skills of male $(\mathrm{SO}=164.99)$ and female students $(\mathrm{SO}=218.71)$. as a result of the data, it was seen that the reading comprehension skill of female students was higher than the male students.

In Çeliköz's [51] study that was completed in 10 different cities and covering 3573 students for the aim of determining the dominant intelligence types of Turkish students, it was seen that female students have mainly verbal intelligence and male students have dominantly mathematical intelligence. As referring that result, it can be said that since female students have mainly used verbal intelligence, they can be more successful in reading comprehension. In many different studies, it was also stated that there was a mean difference between two genders in terms of reading comprehension skills [8,51, 52, 53].

The result of the mean differences on the male students' reading comprehension skill was found via Wilcoxon Signed Rank Test and it is listed in Table 9.

Table 9. The Statement of Differences for the Male Students' Reading Comprehension Skills on Sentiments The Results of Wilcoxon Signed Rank Test

\begin{tabular}{|c|c|c|c|c|c|c|}
\hline Score & Ranks & $\mathrm{N}$ & Mean Rank & Total Rank & $\mathrm{z}$ & $\mathrm{p}$ \\
\hline \multirow{3}{*}{ Happiness-Fear } & Negative Rank & 23 & 37,97 & 873,50 & \multirow{3}{*}{-10.172} & \multirow{3}{*}{.000} \\
\hline & Positive Rank & 152 & 95,56 & 14526,50 & & \\
\hline & Equal & 3 & & & & \\
\hline \multirow{3}{*}{ Sorrow - Fear } & Negative Rank & 98 & 89,56 & 8777,00 & \multirow{3}{*}{-1.461} & \multirow{3}{*}{.144} \\
\hline & Positive Rank & 78 & 87,16 & 6799,00 & & \\
\hline & Equal & 2 & & & & \\
\hline \multirow{3}{*}{$\begin{array}{l}\text { Sorrow- } \\
\text { Happiness }\end{array}$} & Negative Rank & 19 & 47,68 & 906,00 & \multirow{3}{*}{-10.034} & \multirow{3}{*}{.000} \\
\hline & Positive Rank & 154 & 91,85 & 14145,00 & & \\
\hline & Equal & 5 & & & & \\
\hline
\end{tabular}

As a result of Wilcoxon Signed Rank Test, it was seen that the mean score of the male students for the texts consisting of happiness was $(\overline{\mathrm{X}}=88.41)$ and the mean score of the texts consisting of fear was $(\bar{X}=72.90)$. When Table 9 was analyzed, it was seen that there was a statistically mean difference $\left(\mathrm{z}_{\text {happiness-fear }}\right.$ 
$=-10.172, \mathrm{p}<.05)$. In Table 9, it was seen that the mean score of the male students for the texts consisting of fear was $(\overline{\mathrm{X}}=72.90)$ and the mean score of the texts consisting of sorrow was $(\overline{\mathrm{X}}=71.37)$. But, when Table 9 was analyzed, it was seen that there was not a statistically mean difference $(\mathrm{z}$ fear-sorrow $=-1.461, \mathrm{p}<.05)$. The male student can learn to ignore or suppress their negative emotions since those emotions have been accepted as feminine sentiments in Turkish culture [54]. The reason of having not a mean difference between sorrow and fear can be about male students' negative perspective on those two concepts and trying to ignore them.

It was also seen that the mean score of the male students for the texts consisting of happiness was $(\overline{\mathrm{X}}=88.41)$ and the mean score of the texts consisting of sorrow was $(\overline{\mathrm{X}}=71.37)$. When Table 9 was analyzed, it was seen that there was a statistically mean difference $\left(z_{\text {sorrow-happiness }}=-10.034, \mathrm{p}<.05\right)$.

The result of the mean differences on the female students' reading comprehension skill was found via Wilcoxon Signed Rank Test and it is given in Table 10.

Table 10. The Statement of Differences for the Female Students' Reading Comprehension Skills on

\begin{tabular}{lllllll}
\multicolumn{7}{c}{ Sentiments - The Results of Wilcoxon Signed Rank Test } \\
\hline Score & Ranks & $\mathrm{N}$ & Mean Rank & Total Rank & $\mathrm{z}$ & $\mathrm{p}$ \\
\hline \multirow{2}{*}{ Happiness- } & Negative Rank & 24 & 35,02 & 840,50 & & \\
Fear & Positive Rank & 183 & 113,05 & 20687,50 & -11.501 & .000 \\
& Equal & 2 & & & & \\
\multirow{2}{*}{ Sorrow-Fear } & Negative Rank & 124 & 111,81 & 13865,00 & & \multirow{5}{*}{001} \\
& Positive Rank & 84 & 93,70 & 7871,00 & $-3,449$ & \\
& Equal & 1 & & & & \\
Sorrow- & Negative Rank & 14 & 70,57 & 988,00 & & \\
Happiness & Positive Rank & 194 & 106,95 & 20748,00 & -11.369 & .000 \\
& Equal & 1 & & & & \\
\hline
\end{tabular}

As a result of Wilcoxon Signed Rank Test, it was seen that the mean score of the female students for the texts consisting of happiness was $(\bar{X}=95.05)$ higher than the mean score of the texts consisting of fear $(\overline{\mathrm{X}}=79.50)$. When Table 10 was analyzed, it was seen that there was a statistically mean difference $\left(\mathrm{z}_{\text {happiness- }}\right.$ fear $=-11.501, \mathrm{p}<.05)$. In Table 6 , it was seen that the mean score of the female students for the texts consisting of fear was $(\bar{X}=79.50)$ higher than the mean score of the texts consisting of sorrow $(\bar{X}=76.27)$. When Table 10 was analyzed, it was seen that there was a statistically mean difference $(\mathrm{z}$ fear-sorrow $=-3.449$, $\mathrm{p}<.05)$. It was also seen that the mean score of the female students for the texts consisting of happiness was $(\bar{X}=95.05)$ higher than the mean score of the texts consisting of sorrow $(\bar{X}=71.27)$. When Table 10 was analyzed, it was seen that there was a statistically mean difference $\left(\mathrm{z}_{\text {sorrow-happiness }}=-11.369, \mathrm{p}<.05\right)$.

In the studies on this field, it is seen that females can easily reflect their own emotions, they feel stronger the emotions and they have more positive attitudes for the emotions $[55,46]$.

Mann Whitney - U test results that were collected in the study for the reading comprehension statements of the students on sentiments in terms of gender differences is explained in Table 11.

Table 11. Mann Whitney - U test results for the reading comprehension statements of the students on Sentiments in terms of gender differences

\begin{tabular}{llllll}
\hline Text & Gender & $\mathrm{N}$ & Mean Rank & Total Rank & $\mathrm{u}$ \\
\hline Texts consisting of & Female & 178 & 167.69 & 29849,50 & 13918,50 \\
Fear & Male & 208 & 216.40 & 45228,50 & .000 \\
Texts consisting of & Female & 178 & 173.37 & 29758,50 & 14929,00 \\
Sorrow & Male & 209 & 211.57 & 45319,50 & .001 \\
Texts consisting of & Female & 178 & 167.18 & 30860,00 & 13827,50 \\
Happiness & Male & 209 & 216.84 & 44218,00 & .000 \\
\hline
\end{tabular}

As a result of Mann Whitney-U Test, it was seen that the mean score of the female students for the texts consisting of fear was $(\bar{X}=79.50)$ higher than the mean score of the male students $(\bar{X}=72.90)$. When Table 11 was analyzed, it was seen that there was a statistically mean difference $(p<.05)$.

As a result of Mann Whitney-U Test, it was seen that the mean score of the female students for the texts consisting of sorrow was $(\overline{\mathrm{X}}=76.27)$ higher than the mean score of the male students $(\overline{\mathrm{X}}=71.37)$. When Table 11 was analyzed, it was seen that there was a statistically mean difference $(\mathrm{p}<.05)$. 
As a result of Mann Whitney-U Test, it was also seen that the mean score of the female students for the texts consisting of happiness was $(\overline{\mathrm{X}}=95.05)$ higher than the mean score of the male students $(\overline{\mathrm{X}}=88.41)$. When Table 11 was analyzed, it was seen that there was a statistically mean difference $(\mathrm{p}<.05)$.

It was seen that the total score of the female students was higher than the male students for all of the sentiments. In the studies consisting of the knowledge about emotional intelligence, it has been stated that females have higher scores than males in general $[56,57,58]$

According to the result of this study, it was seen that the reflection level of the female students for negative emotions was higher the male students. The reason of it can be about the idea that some emotions such as sorrow, grief and compassion are dedicated to females; it can be about infusions given to males on controlling their emotions [59]. Having strong emotions and reflecting emotion easily may help females to comprehend some reading texts consisting of negative sentiments. Accordingly, it can help the female students on reflecting different emotions and having different experiences.

\section{CONCLUSION}

For the first sub-problem of the study, the reading comprehension skills of the $4^{\text {th }}$ graders, the level of the reading comprehension, gender differences in terms of reading comprehension, the level of reading comprehension in terms of in-depth and superficial reading comprehension and the gender differences in terms of in-depth and superficial reading comprehension skills of the students were examined. In the study, firstly, the current position of the students for the reading comprehension skill was analyzed. The current position of the students in this manner was determined as in frustrational level. The results of the study about the gender differences suggest that the arithmetic mean of the female students was higher than the male students for the reading comprehension skill. According to this result, female students were more successful than the male students during a reading comprehension activity. For the in-depth and superficial reading comprehension skills, it was found that the superficial reading comprehension level of the students was in instructional level; however they were generally in frustrational level for the in-depth reading comprehension skill.

For the second sub-problem of the study, the reading comprehension skills of the $4^{\text {th }}$ graders in terms of sentiments and gender differences in terms of reading comprehension skills of the students were examined. The students were mostly successful for the texts consisting of the sentiments namely happiness. It was also stated that the least success was seen in the texts consisting of sorrow. In general, the success order of the students for the sentiments given in the reading text was given as happiness, fear and sorrow. When the analysis of gender differences was examined, it was seen that the female students were more successful than the male students for all of the sentiments given in the reading texts.

In this study, it was seen that the score of the happiness was higher than the sentiment of fear given in texts. It was also seen that there was a mean difference between two sentiments. It was seen that the score of the fear was higher than the sentiment of sorrow given in texts. It was also seen that there was a mean difference between two sentiments. It was seen that the score of the happiness was higher than the sentiment of sorrow given in texts. It was also seen that there was a mean difference between two sentiments. In this study, it was found that the level of reading comprehension was different from each other in terms of the sentiments given in the texts. The students were successful in the sentiments as order of happiness, fear and sorrow.

In this study, the gender differences of the students in terms of reading comprehension were analyzed. It was determined that there was a meaningful difference between female and male participants. The reading comprehension position of the male students was examined. It was determined that there was a mean difference between the comprehension of texts consisting of happiness and texts consisting of sorrow and fear for the male students. In this case, it was seen that the male students were more successful while reading texts consisting of happiness. However, there was not a mean difference between the sentiments namely sorrow and fear for the male students. The reading comprehension position of the female students was examined. It was determined that there was a mean difference between the comprehension of texts consisting of happiness and texts consisting of sorrow and fear for the female students. In contrast to the male students, it was seen that there was mean difference between sorrow and fear for the female students. In this case, it was stated that the reading comprehension skills of the female students on the texts consisting of happiness were higher than the sentiments of sorrow and fear; and they were more successful in texts consisting of fear than the texts consisting of sorrow. 


\section{REFERENCES}

[1] Razon, N. Pedagoji dergisi sayı 1.İstanbul: Edebiyat Fakültesi Basımevi. 1980.

[2] Stanovich, K.E, "Matthew effects in reading: Some consequences of individual differences in the acquisition of literacy", Reading Research Quarterly, 21(4), 360-407, 1986.

[3] Güneş, F. Hızlı okuma ve anlamı yapılandırma. Ankara: Nobel Yayın Dağıtım; 2009.

[4] National Reading Panel (NRP), "Teaching Children to Read: An Evidence- Based Asessment of The Scientific Research Literature on Reading and İts İmplications for Reading İnstruction: Report of The Subgroups". 2000 Retrieved from https://www.nichd.nih.gov/publications/pubs/nrp/documents/report.pdf

[5] Guthrie, J.T. "Classroom contexts for engaged reading: An overview. In J.T. Guthrie, A. Wigfield, \& K.C. Perencevich (Eds.)", Motivating reading comprehension: Concept-Oriented Reading Instruction (pp. 1-24). Mahwah, NJ: Erlbaum. 2004.

[6] Guthrie, J.T., Klauda, S.L., \& Ho, A.N. "Modeling the relationships among reading instruction, motivation, engagement, and achievement for adolescents". Reading Research Quarterly, 48(1), 9-26. 2013. doi: $10.1002 /$ rrq.035

[7] Pardo, L. S. "What every teacher needs to know about comprehension". The Reading Teacher, 58(3), 272-280; 2004. doi: $10.1598 /$ rt.58.3.5

[8] Sidekli, S. "İlköğretim Beşinci Sınıf Öğrencilerinin Öğretici ve Öyküleyici Metinlere Göre Okuduğunu Anlama Becerilerinin Sınanması”. (Yayımlanmamış Yüksek Lisans Tezi). Gazi Üniversitesi: Ankara; 2005.

[9] Kim, J. S., Hemphill, L., Troyer, M., Thomson, J. M., Jones, S. M., LaRusso, M. D., \& Donovan, S. "Engaging struggling adolescent readers to improve reading skills". Reading Research Quarterly, 52(3), 357-382; 2017.

[10] Menon, S., \& Hiebert, E.H. "A comparison of first graders' reading with little books or literature-based basal anthologies". Reading Research Quarterly, 40(1), 12-38; 2005. doi:10.1598/RRQ.40.1.2

[11] Wigfield, A., \& Eccles, J. "Expectancy-value theory of achievement motivation". Contemporary Educational Psychology, 25(1), 68-81; 2000. doi:10.1006/ceps.1999.1015

[12] Wolters, C.A., Denton, C.A., York, M.J., \& Francis, D.J. “Adolescents' motivation for reading: Group differences and relation to standardized achievement". Reading and Writing, 27(3), 503-533; 2014. doi:10.1007/s11145-0139454-3

[13] Baker, T., \& Wigfield, A. "Dimensions of children's motivation for reading and their relations to reading activity and reading achievement". Reading Research Quarterly, 34, 2- 29; 1999.

[14] Wigfield, A. \& Guthrie, J. T. "Relations of children's motivation for reading to the amount and breadth of their reading". Journal of Educational Psychology, 89 (3), 420-432; 1997. doi: 10.1037//0022-0663.89.3.420

[15] Güneş, F. "Uzmanlardan ailelere çocuk kitabı uyarısı". TRT Haber. 2015. Retrieved from: http://www.trthaber.com/haber/egitim/uzmanlardan-ailelere-cocuk-kitabi-uyarisi-207536.html.

[16] Karadağ, İ. "İlköğretim Beşinci Sınıf Öğrencilerinin Akademik Başarılarının Sosyal Destek Kaynakları Açısından İncelenmesi. (Yayımlanmamış Yüksek Lisans Tezi). Çukurova Üniversitesi: Adana; 2007.

[17] Tarhan, N. "Ergenlerin Sosyometrik Stratejileri, Cinsiyetleri, Akademik Başarıları, Sınıf Düzeyleri ve Devam Ettikleri Sosyo-Ekonomik Statüsü İle Duyguları Arasındaki İlişki”. VII. Eğitim Bilimleri Ulusal Eğitim Kongresinde sunulmuştur, Konya. 1994.

[18] Karasar, N. Bilimsel araştırma metodu. Ankara: Hacettepe Taş Kitapçılık. 2000.

[19] Oakhill, J.V., \& Petrides, A. "Sex differences in the effects of interest on boys' and girls' reading comprehension". British Journal of Psychology, 98(2), 223-235. 2007. doi:10.1348/000712606X117649

[20] Özkara, Y. Okuma güçlüğü olan öğrencilerin okuma düzeylerinin gelişti-rilmesine yönelik bir uygulama. Pamukkale Üniversitesi Sosyal Bilimler Üniversitesi Dergisi, 5, 109-119; 2010.

[21] Sidekli, S. ve Yangın S. Okuma Güçlüğü Olan Öğrencilerin Okuma Becerilerinin Geliştirilmesine Yönelik Bir Uygulama. Atatürk Üniversitesi Kazım Karabekir Eğitim Fakültesi Dergisi, 11, 393-413; 2005.

[22] Sidekli, S. "Eylem araştırması: ilköğretim dördüncü sınıf öğrencilerinin okuma ve anlama güçlüklerinin giderilmesi”. Türklük Bilimi Araştırmalarl, 27(27), 563-580; 2010.

[23] MEB, "PISA 2003 Türkiye Ulusal Nihai Raporu”. Millî Eğitim Bakanlığı, Eğitimi Araştırma ve Geliştirme Dairesi Başkanlığı, Ankara; 2003.

[24] MEB, "PISA 2015 Ulusal Nihai Raporu”. Millî Eğitim Bakanlığı, Ölçme, Değerlendirme ve Sınav Hizmetleri Genel Müdürlüğü, Ankara; 2016.

[25] Ergenç, İ. "Beyindeki dil”. TÜBITTAK Bilim ve Teknik Dergisi, 314, 36-39; 1994.

[26] Korkmaz, Ö. ve Mahiroğlu A. "Beyin, bellek ve öğrenme”. Kastamonu Eğitim Dergisi, 15(1), 93-104; 2007.

[27] Tarhan, N. Duygıuların psikolojisi. İstanbul: Timaş Yayınları; 2016.

[28] Demirel, Ö., Kuramdan uygulamaya eğitimde program geliștirme. Ankara: Pegem A Yayınc1lı; 2003.

[29] Healy, J. M. Çocuğunuzun gelişen akll-doğumdan ergenliği öğrenme ve beyin gelişimi.(Çev.: Ayşe Bilge Dicleli), İstanbul: Boyner Holding Yayınları; 1999.

[30] Mullis, I.V.S., Martin, M.O., Gonzalez, E.J. \& Kennedy, A.M. "PIRLS 2001 international report: IEA's study of reading literacy achievement in primary schools in 35 countries". Chestnut Hill, MA: Boston College. 2003. Retrieved from https://timss.bc.edu/pirls2001i/pdf/p1_IR_book.pdf

[31] OECD, "PISA 2015 Assessment and analytical framework: science, reading, mathematic and financial literacy". PISA, Paris: OECD Publishing; 2016.

[32] Phakiti, A. “A closer look at gender and strategy use in L2 reading”. Language learning, 53(4), 649-702; 2003.

[33] Pomerantz, E.M., Altermatt, E. R. \& Saxon, L. J. "Making the grade but feeling distressed: Gender differences in academic performance and internal distress. Journal of Education Psychology, 94(2), 396-404; 2002.

IJERE Vol. 7, No. 4, December 2018 : $317-330$ 
[34] Schwabe, F., McElvany, N., \& Trendtel, M. "The school age gender gap in reading achievement: Examining the influences of item format and intrinsic reading motivation". Reading Research Quarterly, 50(2), 219-232; 2015.

[35] Sidekli, S. İlköğretim 5. Sınıf Öğrencilerinin Okuma Ve Anlama Becerilerini Geliştirme (Eylem Araştırması). (Yayımlanmamış Doktora Tezi). Gazi Üniversitesi: Ankara; 2010.

[36] Ciecierski, L. M. "What the Common Core State Standards do not tell you about connecting texts". The Reading Teacher, 71(3), 285-294; 2017.

[37] Manak, J. "The Social Construction of Intertextuality and Literary Understanding: The Impact of Interactive Read-Alouds on the Writing of Third Graders During Writing Workshop”. Reading Research Quarterly, 46(4), 309$311 ; 2011$.

[38] Ozuru, Y., Dempsey, K., \& McNamara, D.S. "Prior knowledge, reading skill, and text cohesion in the comprehension of science texts". Learning and Instruction, 19 (3), 228 -242; 2009.

[39] Rapp, D.N., van den Broek, P., McMaster, K.L., Kendeou, P., \& Espin, C.A. "Higherorder comprehension processes in struggling readers: A perspective for research and intervention”. Scientific Studies of Reading, 11 (4), 289 - 312; 2007.

[40] Yörükoğlu, A. Çocuk ruh sağglı̆̆l. İstanbul: Özgür Yayınları; 1998.

[41] Ellison, L. The personal intelligences: promoting social emotional learning. Corwin Press Inc; 2000.

[42] Goleman, D. Duygusal zeka. İstanbul: Varlık Yayınları; 2016.

[43] Tendler, A., ve Wagner, S. Different types of theta rhythmicity are induced by social and fearful stimuli in a network associated with social memory. Elife, 4, e03614; 2015.

[44] Gür, Ö. Yetişkinlere Yönelik Yabancı Dil Olarak Almanca Öğretiminde Gülerek Öğrenmenin Başarıya Etkisi. (Yayımlanmamış Doktora Tezi). İstanbul Üniversitesi: İstanbul; 2010.

[45] Ashby, F. G., Isen A. M. \& Turken A. U., "A neuropsychological theory of positive affect and its influence on cognition". Psychological Review, 106(3), 529-550, 1999.

[46] Larsen, R. J. \& Diener E. "Affect intensity as a individual difference characteristic: a review. Journal of Research in Personality, 21(1), 1-39; 1983.

[47] Duyan, V., Uçar, M. ve Kalafat, T. 'Duygu gereksinimi ölçeği’Nin türk kültürüne uyarlanması ve psikometrik niteliklerinin belirlenmesi”. Eğitim ve Bilim Dergisi, 36(161). 116-130; 2011.

[48] Bernet, M. "Emotional intelligence: components and correlates". Paper presented at the Annual Meeting of the American Psychological Association, Canada; 1996.

[49] Spitzer, M. Lernen gehirnforschung und die schule des lebens. Heidelberg: Spektrum Akademischer Verlag; 2002.

[50] Ömeroğlu, E. ve Ulutaş, İ. Çocuk ve ergen gelişimi. İstanbul: Morpa; 2007.

[51] Çeliköz, N. "Kızlar Sözel Erkekler Sayısal Zekalı". Haberciniz. 2009 Retrieved from: http://www.haberciniz.biz/kizlar-sozel-erkekler-sayisal-zekali-21961h.htm

[52] Brantmeier, C. A. "The relationship between readers' gender, passage content, comprehension and strategy use in reading Spanish as a second language". Foreign Language Annals, 34(4), 325-333; 2001. doi: 10.1111/j.19449720.2001.tb02064.x

[53] Kurdek, A. L. ve Sinclair, R. J. "Predicting reading and mathematics achievement in fourth-grade children from kindergarten readiness scores". Journal of Educational Psyhology, 93(3), 451-455; 2001.

[54] Işık, A. Z. Duygu-Biliş Etkileşim Ölçeği’nin Geliştirilmesi Ve Duygu Bilişin, Üniversite Öğrencilerinde Cinsiyet, Yaş Ve Bölüm Açısından İncelenmesi.(Yayımlanmamış Doktora Tezi). Marmara Üniversitesi: İstanbul; 2007.

[55] Clancy, S. M. \& Dollinger, S. J. "Photographic depictions of the self: Gender and age differences in social connectedness". Sex Roles, 29(7-8), 477-495; 1993.

[56] Austin, E.J., Evans, P., Goldwater, R. \& Potter, V. "A preliminary study of emotional intelligence, empathy and exam performance in first year medical students". Personality and Individual Differences, 39(8); 2005.

[57] Doğan, U. Lise Öğrencilerinin Duygusal Zekâ Düzeyleri İle Problem Çözme Becerilerinin Bazı Değişkenlere Göre İncelenmesi. (Yayımlanmamış Yüksek Lisans Tezi). Muğla Üniversitesi: Muğla; 2009.

[58] Mayer, J. D., Caruso, D. R. \& Salovey, P. "Emotional intelligence meets traditional standards for intelligence". Intelligence, 27(4), 267-298; 1999.

[59] Feldman Baret, L.,Lane, R.D., Sechrest, L. \& Schwartz, G. E. "Sex differences in emotional awareness”. Personality and Social Psychology Bulletin, 26(9), 1027-1035; 2000.

[60] Büyüköztürk, Ş. Sosyal bilimler için veri analizi el kitabı. Ankara: Pegem A Yayıncılık; 2012.

[61] McKenna, M.C. \& Stahl, S.A. Assessment for reading instruction. New York: The Guilford Pres; 2005. 


\section{BIOGRAPHIES OF AUTHORS}

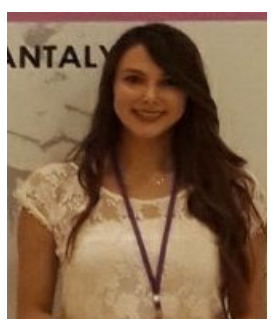

Esra ÇETIN completed her BA Degree at Gazi University, Gazi Faculty of Eduction, Primary Education Program and completed her MA Degrees at Muğla Sitkı Koçman Universty, Primary Education Program. She has been doing her PhD at Uludağ Universty, Primary Education Program. Her research interests are reading and writing, comprehension reading and meta anaylsis.

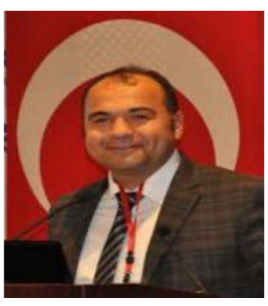

Assoc. Prof. Dr. Sabri SIDEKLİ completed his BA Degree at Atatürk University, Kazım Karabekir Faculty of Education, Primary Education Program and completed his MA and $\mathrm{PhD}$ Degrees at Gazi University, Primary Education Program. He has been working at Muğla Sitk1 Koçman University, Faculty of Education, Elementary Education Department, Primary Education Program. His research interests are primary teacher training, reading and writing disability, skills education, new approaches in teaching and learning, and assessment and evaluation. 